\title{
Effects of Alien Plants on Insect Abundance and Biomass: a Food-Web Approach
}

\author{
RÚBEN H. HELENO,${ }^{*} \dagger$ RICARDO S. CEIA, $†$ JAIME A. RAMOS, $†$ AND JANE MEMMOTT* $\ddagger$ \\ ${ }^{*}$ School of Biological Sciences, University of Bristol, Bristol BS8 1UG, United Kingdom \\ †Institute of Marine Research (IMAR), Department of Zoology, University of Coimbra, 3004-517 Coimbra, Portugal
}

\begin{abstract}
The replacement of native plants by alien species is likely to affect other trophic levels, particularly phytophagous insects. Nevertheless, the effect of alien plants on insect biomass has not yet been quantified. Given their critical role in transferring energy from plants to bigher trophic levels, if alien plants do affect insect biomass, this could have far-reaching consequences for community structure. We used 35 food webs to evaluate the impacts of alien plants on insect productivity in a native forest in the Azores. Our food webs quantified plants, insect berbivores, and their parasitoids, which allowed us to test the effects of alien plants on species richness and evenness, insect abundance, insect biomass, and food-web structure. Species richness of plants and insects, along with plant species evenness, declined as the level of plant invasion increased. Nevertheless, none of the 4 quantitative food-web descriptors (number of links, link density, connectance, and interaction evenness) varied significantly with plant invasion independent of the size of the food web. Overall, insect abundance was not significantly affected by alien plants, but insect biomass was significantly reduced. This effect was due to the replacement of large insects on native plants with small insects on alien plants. Furthermore, the impact of alien plants was sufficiently severe to invert the otherwise expected pattern of species-richness decline with increased elevation. We predict a decrease in insect productivity by over $67 \%$ if conservation efforts fail to balt the invasion of alien plants in the Azores.
\end{abstract}

Keywords: Azores, biodiversity, biological invasions, exotic plants, food webs, laurel forest, parasitoid, seed herbivore

Efectos de Plantas Exóticas sobre la Abundancia y Biomasa de Insectos: un Enfoque de Red Alimenticia

Resumen: Es probable que el reemplazo de plantas nativas por especies invasoras afecte otros niveles tróficos, particularmente insectos fitófagos. Sin embargo, el efecto de plantas invasoras sobre la biomasa de insectos aun no ba sido cuantificada. Debido a su papel crítico en la transferencia de energía de las plantas a niveles tróficos superiores, sí las plantas exóticas afectan la biomasa de insectos, esto podría tener mayores consecuencias sobre la estructura de la comunidad. Utilizamos 35 redes alimenticias para evaluar los impactos de plantas invasoras sobre la productividad de insectos en un bosque nativo en las Azores. Nuestras redes alimenticias cuantificaron plantas, insectos berbívoros y sus parasitoides, lo que nos permitió probar los efectos de plantas exóticas sobre la riqueza y equitabilidad de especies de plantas, abundancia de insectos, biomasa de insectos y estructura de la red alimenticia. La riqueza de especies de plantas e insectos, junto con la equitabilidad de especies de plantas, declinó a medida que incrementó la invasión de plantas. Sin embargo, ninguno de los cuatro descriptores cuantitativos de la red alimenticia (número de eslabones, densidad de eslabones, conectividad, equitabilidad de interacción) varió significativamente con la invasión de plantas independientemente del tamaño de la red alimenticia. La abundancia total de insectos no fue afectada significativamente por las plantas exóticas, pero la biomasa de insectos se redujo significativamente. Este efecto se debió al reemplazo de insectos grandes en plantas nativas por insectos pequeños sobre plantas exóticas. Más aun, el impacto de las plantas exóticas fue suficientemente severo 
para invertir el patrón esperado de declinación en la riqueza de especies con el incremento de elevación. Pronosticamos un decremento mayor a $67 \%$ en la productividad de insectos si los esfuerzos de conservación no detienen la invasión de plantas exóticas en las Azores.

Palabras Clave: Azores, biodiversidad, bosque laurel, herbívoro de semillas, invasiones biológicas, parasitoide, plantas exóticas, redes alimenticias

\section{Introduction}

Nonindigenous species (hereafter referred to as aliens) establish outside their historical natural range. Some aliens have the potential to spread and become invasive and can be detrimental to the environment. Few if any habitats remain free of their influence, and they have resulted in an unprecedented alteration in the distribution of the Earth's biota (Mack et al. 2000) and serious consequences for ecological, economic, and social systems (Davis et al. 2000). Consequently, biological invasions have been considered the second-largest cause of the loss of biodiversity, following habitat loss (Vitousek et al. 1997), and small, isolated areas, such as oceanic islands, are particularly vulnerable (Leeuwen et al. 2005). Lonsdale (1999) estimates that islands possess 2.6 times as many alien plant species as mainland sites of similar native diversity, a statistic which is particularly worrying given that island ecosystems typically support unique biotic communities rich in endemic taxa (Whittaker \& FernandezPalacios 2007). It is therefore increasingly crucial to understand the impacts of biological invasions, particularly on oceanic islands.

Invaders can change the structure and composition of ecological communities (Lopezaraiza-Mikel et al. 2007; Aizen et al. 2008) and alter a range of ecosystem processes such as nutrient cycling (e.g., Ehrenfeld 2003) and disturbance regimes (Brooks et al. 2004). Whether an invader establishes, and the impact it has, is determined at least in part by interactions between that species and the recipient community (Mack et al. 2000). Nevertheless, the impact of aliens on higher trophic levels remains one of the least-studied areas of invasion biology (Bartomeus et al. 2008). No one has yet designed a study to measure the impact of alien plants on the production of insect biomass (Tallamy 2004). Given the importance of insects in the provision of ecosystem services (Losey \& Vaughan 2006), and with many studies linking the fitness of vertebrate predators to the quantity and quality of insect food supplies (e.g., Oliver 1998), understanding the impact of alien species on food-web structure and insect biomass is essential if ecologists are to understand the full impact of alien plants on natural habitats (Aizen et al. 2008).

Working in the highly invaded native laurel forest in the Azores archipelago, we constructed food webs with the aim of measuring the impact of alien plants on the productivity of 3 trophic levels: fruits and seeds, insect herbi- vores, and the insect's parasitoids. Previous researchers focused on the impact of alien species within a single taxonomic group (Sax et al. 2005) and, on the rare occasions when community-level impacts were measured, considered only species number (Parker et al. 1999). A food-web approach has 2 particular advantages. First, it provided a sampling method that yielded data on species richness and abundance at multiple trophic levels and on the frequency of interactions between trophic levels. This allowed calculations to be made on how productivity at one trophic level affected that at another level. Second, it enabled us to explore how alien plants affect food-web structure.

We had 5 objectives in this study: characterize the food web that links plants, herbivores, and parasitoids together and evaluate how alien plants integrate into the native community; determine the impact of alien plants on species richness, species evenness, and quantitative foodweb descriptors; quantify the impact of alien plants on overall insect availability to other trophic levels measured in terms of insect abundance and insect biomass; measure the impact of alien plants on variability in seed supply to higher trophic levels; and predict insect biomass production under 2 scenarios (full restoration of the native laurel forest and total replacement of all native vegetation with aliens).

Specialist enemies of alien plants are usually missing in an exotic range, and generalist herbivores are predicted to have a greater effect on the native flora than on alien species (enemy release hypothesis; reviewed in Keane \& Crawley 2002); therefore, we expected that alien plants would have fewer herbivores than native plants. We also predicted that native plant diversity would decrease following the invasion of alien plants and that this decrease would affect diversity at higher trophic levels (Tallamy 2004). In invaded areas food webs will also become impoverished, and this is likely to affect food-web descriptors (Tylianakis et al. 2007). Thus, we predicted that both insect abundance and biomass would decrease as alien plants with few herbivores replaced native plants with many herbivores (Tallamy 2004; Carpenter \& Cappuccino 2005). We also predicted that as the rich native flora was replaced by a few dominant alien plants, the temporal variability in seed supply would increase because there would be fewer plants seeding throughout the year (i.e., redundancy in seeding phenology would be reduced). 


\section{Methods}

\section{Field Sites}

We constructed food webs for the island of São Miguel, the largest of the 9 islands in the Azores archipelago. The Azores are characterized by a temperate oceanic climate with moderate rainfall spread evenly throughout the year, high relative humidity, and a small temperature range (Silva \& Smith 2006). The field sites were located in Serra da Tronqueira, a mountainous district on the east of São Miguel $\left(37^{\circ} 47^{\prime} \mathrm{N}, 25^{\circ} 13^{\prime} \mathrm{W}\right)$ that is densely vegetated with native and alien flora (Ramos 1996) and part of the Special Protected Area (SPA) of Pico da Vara and Ribeira do Guilherme.

Native vegetation to the east of São Miguel was cleared for pastures, replaced by production forest of Cryptomeria japonica (Japanese red cedar), or taken over by weeds, such as Pittosporum undulatum (Australian cheesewood) on slopes along streams up to $500 \mathrm{~m}$; Hedychium gardneranum (Kahili ginger) on disturbed ground and streams; and Cletbra arborea (Lilly-of-thevalley tree), which is scattered widely throughout the remaining native forest (Ramos 1995). Silva and Smith (2006) report that $64 \%$ out of the 365 plant taxa on São Miguel are nonindigenous, with relatively uninvaded patches of native forest remaining only at high elevation. These native remnants are host to species of particular conservation interest; for example, 8 trees from the original laurel forest are endemic, as is the critically endangered Azores bullfinch (Pyrrbula murina) (IUCN 2005).

\section{Food Web Linking Plants, Herbivores, and Parasitoids}

We sampled 35 plots within the SPA in 2006. To minimize the effect of elevation, we located all plots between 500 and $750 \mathrm{~m}$ asl. Although the level of invasion by alien plants varied, all the plots were in the native laurel forest or along its edges, where the dominant life forms were trees and bushes. Pastures and plantations of $C$. japonica were excluded, because they are not part of natural succession, as were areas with cliffs or other hazardous features. We walked all forest tracks and footpaths and, when the above criteria were met, we gave each site a $50 \%$ chance of being chosen. This $50 \%$ criterion served to spread the transects over the study area (see Supporting Information). All plots were at least $50 \mathrm{~m}$ apart.

The plots were $30 \times 2 \mathrm{~m}$, and we used a centrally placed 30-m linear transect for sampling. We sampled in July, September, and November of 2006, which encompassed the fruiting season of most plant species (Schäffer 2002; R.H.H., unpublished data). We sampled $1 \mathrm{~m}$ either side of the transect line and collected within each transect all seeds and fruits (henceforth referred to collectively as seeds). This sampling provided quantitative plant species richness and abundance data. We inspected each seed for insect exit holes, which we considered evidence of emergence of an herbivore prior to seed collection. Seeds of the same species collected from a transect were placed inside $1 \mathrm{~mm}$ microperforated polypropylene bags $(10 \times$ $15 \mathrm{~cm}$ ). No more than 50 seeds or 30 small fruits were placed inside each bag. Every 4 days for 10 weeks, we counted and identified herbivores and parasitoids that emerged in the bags. All insects were identified to species or morphospecies by taxonomists. Where the collection of all seeds from one species in a transect was impractical due to their high abundance, we collected a subsample of seeds and extrapolated the results for analysis. We dried and weighed the seeds of all abundant species ( $>5 \%$ of the total number of seeds).

We visualized the food webs with a program written in Mathematica 4.0 (Wolfram Research 1999) and calculated herbivore host range as the number of plants from which each herbivore emerged. A mean host range for the herbivores emerging from each plot was calculated and its relationship with the proportion of alien seeds in the plot explored with correlation analysis. We compared the size of native and alien seeds with a one-way analysis of variance (ANOVA) to determine whether changes in insect biomass after invasion were attributable to differences in the size of native and alien seeds.

\section{Biodiversity and Food-Web Structure}

We assessed species richness at all trophic levels for the food webs from the 35 plots. Species evenness, a measure of the relative apportionment of abundances among species (Rousseau \& Van Hecke 1999), was computed by dividing the Shannon index of entropy $\left(H^{\prime}\right)$ by $H_{\max }$ so that it fell between 0 and 1 (Pielou index) (Magurran 2004).

We described food-web structure with the following statistics: number of trophic links, link density (average number of links per species), quantitative connectance (proportion of possible links realized), and interaction evenness (uniformity of link distribution) (Bersier et al. 2002; Tylianakis et al. 2007). Species were classified as top, intermediate, or basal according to their relative position in the food web. Top species had prey, but no consumers. Intermediate species were both prey and consumers. Basal species had consumers but no prey. Although this classification has been used widely in the analysis of food webs with 3 or more trophic levels (e.g., Sugihara et al. 1989; Bersier et al. 2002; Dunne et al. 2004), it does not correspond directly to the classic "trophic levels" (plants, herbivores, parasitoids). Here, basal species are plants, parasitoids are always top species, and herbivores can be either intermediate or top species (depending on whether they have parasitoids or not). Finally, we considered all plants as basal species even if no 
herbivores emerged from their seeds because this provided a more realistic picture of the community.

We used the proportion of alien seeds per site as a covariate in univariate general linear models (GLMs) to assess the impact of alien plants on these community descriptors. The proportion of alien seeds was transformed with Zar's (1999) modification of the angular (arcsine) transformation (Freeman \& Tukey 1950). Given that all hypotheses were formulated a priori (alien plants reduce plant and insect adundance and diversity) and variables were intercorrelated, Bonferroni corrections were considered inappropriate because they would unjustifiably increase the chance of type II errors (Perneger 1998). When a response variable was expected to have a nonlinear response (i.e., a positive response to low levels of invasion and a negative response to high alien plant density [plant species richness and evenness, insect abundance and biomass]), we performed a GLM that included the polynomial term $x^{2}$ as a covariate. It is now commonly accepted that food-web descriptors are to some extent dependent on network size (Bersier \& Sugihara 1997); therefore, it is important to account for network size when exploring the behavior of food-web descriptors (Renner 2007). Consequently, the GLM used to analyze the impact of alien plants on food-web descriptors included species richness and proportion of alien seeds as covariates. Connectance was transformed to its reciprocal.

Elevation was measured at the center of each plot, and the relation between species richness, plant invasion, and elevation was explored with linear regression.

\section{Insect Abundance and Biomass}

To assess the overall availability of insects as prey to other trophic levels, we computed total insect abundance and total insect biomass. Abundance was defined as the total number of all insects that emerged from seeds. We defined biomass as the cumulative weight and used the body length to body mass conversion equations developed by Sample et al. (1993). The impact of the invasion on insect abundance and biomass was assessed by means of univariate GLMs, with the proportion of alien seeds per site as a covariate. Both variables were transformed as $\log x+1$.

\section{Impact of Alien Plants on the Variability in Seed Production}

The sampling periods of July, September, and November corresponded roughly with the start, peak, and end, respectively, of the fruiting season in native habitats in the Azores (R.H.H., personal observation). We compared the pattern of seed production over the fruiting season for highly invaded plots ( $>95 \%$ alien seeds, $n=10$, Table 1 ) and for plots largely dominated by native vegetation $(<5 \%$ alien seeds, $n=11$, Table 1 ). We used a factorial ANOVA to compare the number of seeds produced throughout the fruiting season in native and invaded plots (squareroot transformed) in each sampling period.

\section{Predicting Insect Biomass Production}

Insect production was calculated separately for the highly invaded plots and for native plots. We used the mean insect biomass produced by those 2 groups to estimate the insect production for the entire SPA under 2 scenarios: replacement of the native forest by alien species ( $>95 \%$ alien seeds) and complete recovery from the present invasion to a close to pristine situation ( $<5 \%$ alien seeds). This prediction was made by extrapolating the productivity of native and invaded plots to the total size of the SPA (6067.27 ha).

\section{Results}

Food Web Linking Plants, Herbivores, and Parasitoids

We collected 241,590 seeds and fruits, of which 23,218 (10\%) were placed in the plastic bags. There were 46 seed-producing plant species in the plots. The percentage of alien seeds per plot ranged from 0 to $100 \%$ (mean of $51.2 \%$ [SE 7.2]; Table 1). Seed herbivory was low with 1666 insects emerging from the seeds (infestation rate of $7.1 \%$ ). Nine species of herbivores and 4 species of parasitoids emerged that were linked to each other and to plants by 31 unique interactions (Supporting Information). Space limitations preclude presentation of all 35 networks; instead, 3 networks across a range of invasions are presented in Fig. 1. Level of invasion (\% alien seeds) and the mean host range of the herbivores reared in each plot showed significant positive correlation $(r=0.43, n$ $=33, p=0.014)$. Size of native and alien seeds did not differ significantly (ANOVA, $F=1.58, p=0.214$ ).

\section{Biodiversity and Food-Web Structure}

The relationship between the percentage of alien plants and total species richness, number of plant species, and number of top species (Table 2) was significantly negative. With respect to plants, adding a second-level polynomial covariate considerably increased the fit of the data (Fig. 2; Table 2). Because only 7 of the 35 food webs had intermediate species, the richness of intermediate species did not meet the assumptions of parametric statistics even after transformations were applied; thus, they were excluded from analysis.

In 2 of the highly invaded plots, $H$. gardneranum was the only species for which fruits were collected, which made it impossible to compute evenness (Table 1). We considered evenness of these plots to be equal to the lowest evenness detected because we likely missed rare plants that would have made evenness possible to compute and very low. Species evenness decreased with 


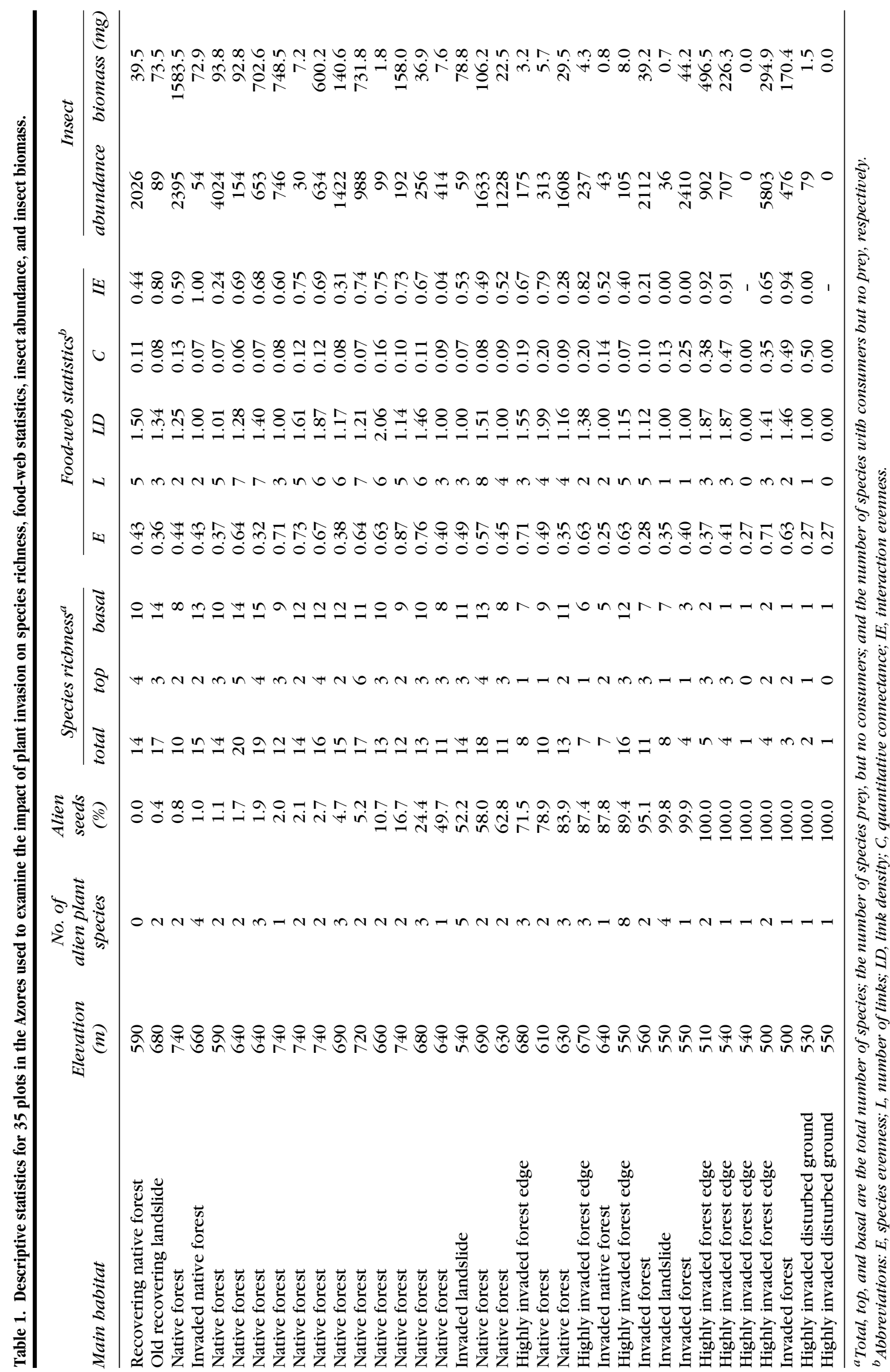


(a) Native plot (4.7\% alien seeds)

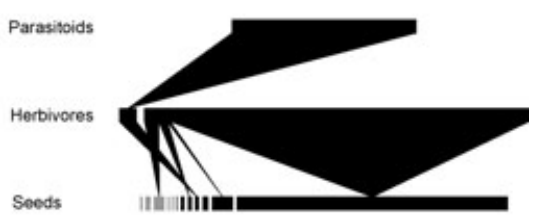

(b) Partially invaded plot (49.7\% alien seeds)

Parasinoids

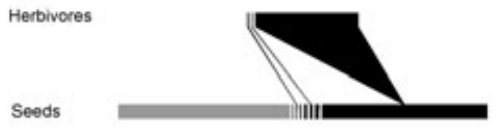

(c) Highly invaded plot (99.8\% alien seeds)

Parasitoids

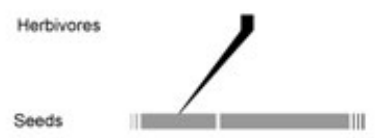

500 seeds 50 herbivores 5 parasitoids

Figure 1. Quantitative food webs from 3 plots with different levels of alien plant invasion: (a) native laurel forest, (b) partially invaded plot, and (c) bighly invaded plot. Each bar represents a species, and width of the bar represents the species' relative abundance among all individuals sampled. The area of the triangles connecting trophic levels represents the relative number of higher-trophic-level species attacking the lower-level species (black, native plants; gray, alien species).

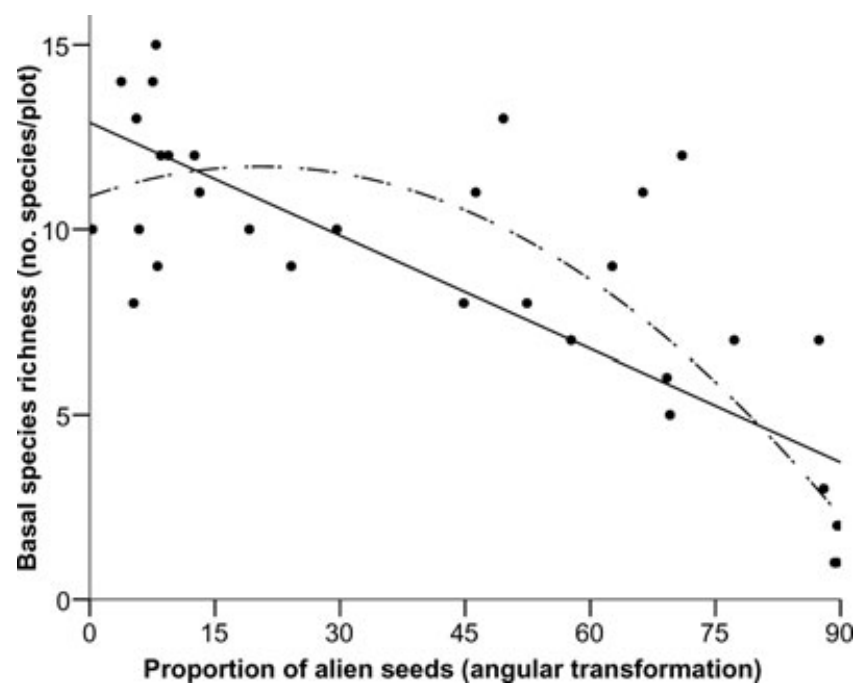

Figure 2. Relationship between basal species richness (plants) and the proportion of alien seeds. Lines represent linear and quadratic models with best fit.

proportion of alien seeds, although this result was only significant when we included a quadratic term in the model (Table 2). After controlling for effect of size of the food web, none of the 4 food-web descriptors were significantly affected by proportion of alien seeds (Table 2).

Even though all plots were located within a small elevational range (500-750 m), species richness was positively correlated with elevation $\left(r_{\text {adj }}=0.334, F_{1,33}=18.05, p<\right.$ 0.001 ). This pattern was probably a consequence of the negative relationship between altitude and the fraction of alien seeds $\left(r_{\mathrm{adj}}=0.557, F_{1,33}=43.73, p<0.001\right)$.

Table 2. Relationships between percentage of alien seeds per plot (after angular transformation) and biodiversity and food-web response variables.

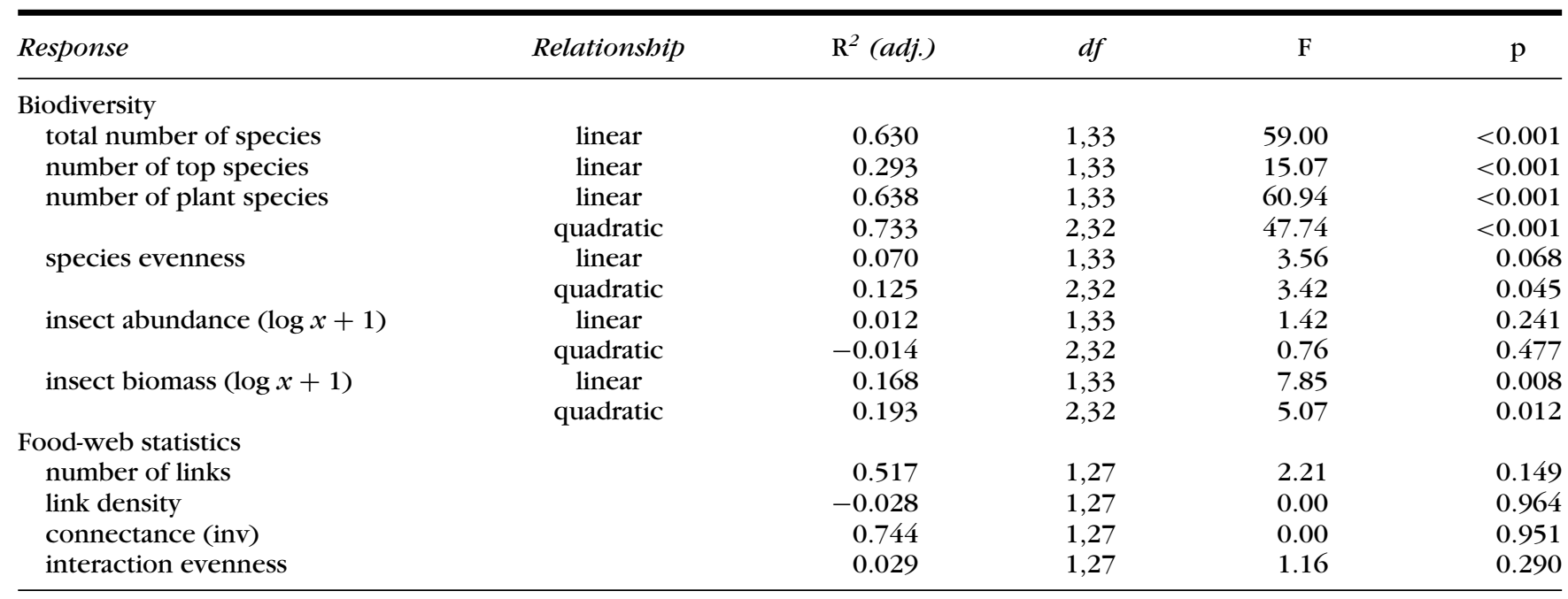




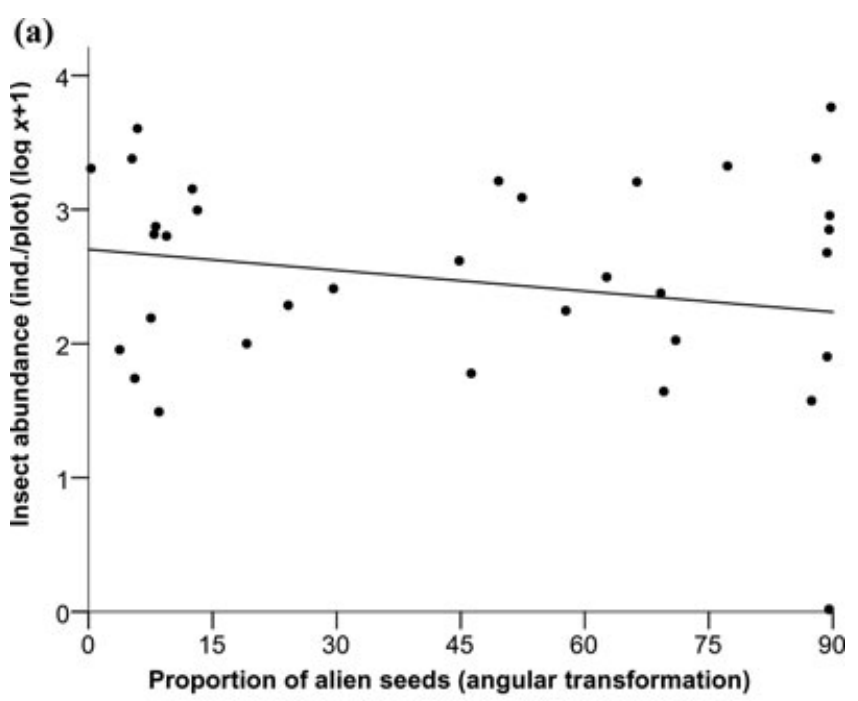

(b)

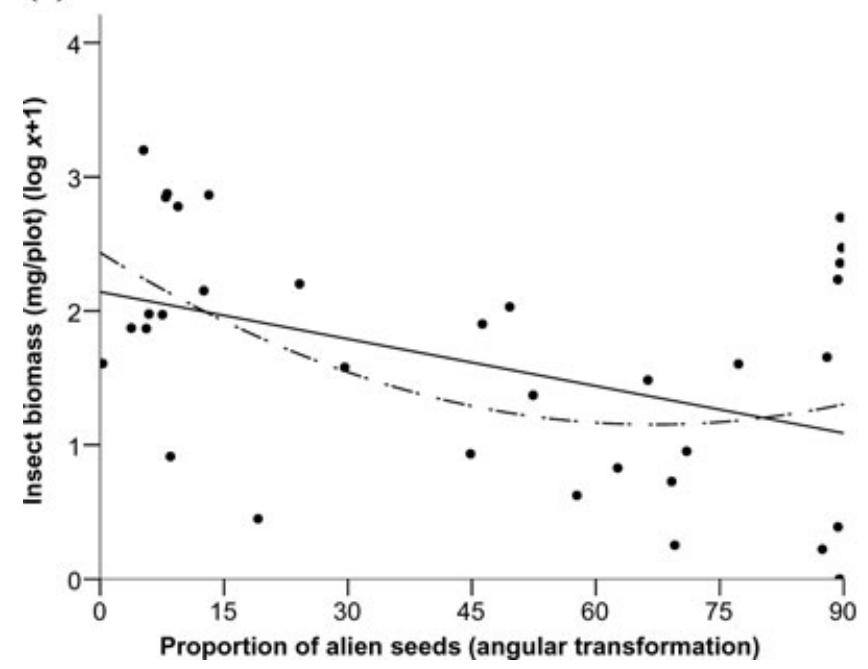

Figure 3. Relationships between (a) log insect abundance and (b) log insect biomass and the proportion of alien plants. Lines represent the linear and quadratic model with best fit.

\section{Insect Abundance and Biomass}

Although insect abundance was not significantly affected by plant invasion (Fig. 3a; Table 2), insect biomass was significantly reduced when we used a quadratic term to improve the fit of the model (Fig. 3b; Table 2). Biomass decreased as the larger herbivores on native plants (e.g., Lepidoptera) were replaced by similar numbers of smaller herbivores, predominantly midges (Diptera: Cecidomidae) on alien plants (Supporting Information).

\section{Impact of Alien Plants on Variability in Seed Production}

The number of seeds produced was significantly affected by the level of invasion $\left(F_{1,57}=9.94, p=0.003\right)$ and sampling period $\left(F_{2,57}=12.77, p<0.001\right)$. There was significant interaction between these 2 variables $\left(F_{2,57}=\right.$ $13.42, p<0.001)$. Native plots produced similar numbers of seeds throughout the year, whereas highly invaded plots produced significantly fewer seeds in July and September (Tukey test, $p<0.018$ ).

\section{Predicting Insect Biomass Production}

In total $6600 \mathrm{mg}$ of insects emerged from seeds collected from the 35 sampled plots, and we estimated that productivity of the SPA, from July to November, was $191 \mathrm{~kg}$ of seed-feeding herbivores (i.e., herbivores and parasitoids). Hereafter, we refer to this productivity as insect biomass per year because few insects emerge during winter (the Azorean winter usually ends in May).

Plots that had $<5 \%$ alien seeds $(n=11)$ produced on average $6.3 \mathrm{mg}$ insect biomass $/ \mathrm{m}^{2}$, whereas plots with $>95 \%$ alien seeds $(n=10)$ produced $2.1 \mathrm{mg} / \mathrm{m}^{2}$. Extrapolating from these values to the total area of the SPA, we estimated that if public and private habitat restoration efforts are successful and the whole area is restored to native laurel forest ( $<5 \%$ alien seeds), the area will produce $392 \mathrm{~kg}$ insect biomass/year, which is double the current biomass. Alternatively, if conservation efforts fail and the remaining native fragments are invaded and replaced by alien flora ( $>95 \%$ alien seeds), the insect production capacity of the SPA will fall by 33\% (or 67\% relatively to the pristine native forest prediction) to $128 \mathrm{~kg}$ insect biomass/year.

\section{Discussion}

The high level of plant invasion into the SPA highlights the fragile conservation status of the last remaining fragment of native forest on the island of São Miguel. Species richness of plants and insects declined with the level of plant invasion, whereas insect abundance was not significantly affected. There was, however, a significant decrease in insect biomass, which would be sufficient to cause a 33\% decrease in insect productivity should the SPA be taken over completely by alien plants.

\section{Study Limitations}

Our methods may have missed spatially or temporally rare interactions, a problem common to all food-web projects. Nevertheless, any bias would have affected all the plots equally, so was unlikely to have influenced our results. We considered only a small part of the herbivore community. Working with a broader taxonomic range of species could lead to a greater understanding of the real impact of alien plants and the underlying processes.

We could only explore the impact of the alien plants present in our study sites, so it is impossible to make generalizations about the impacts of alien plants in other habitats. Global patterns of the impact of alien species 
will become evident once more studies documenting their community-wide impact are published and metaanalysis can be conducted.

\section{The Food Webs}

As expected by virtue of its insularity (Gillespie \& Roderick 2002), the insect community of the laurel forest was relatively simple compared with similar continental studies (e.g., Fonseca et al. 2005). On average, herbivores reared from alien-dominated plots were more generalized than those reared from native plots. This result has been reported in other studies from invaded habitats (e.g., Carpenter \& Cappuccino 2005, for herbivory; Lopezaraiza et al. 2007, for pollination). There was no significant difference in the weight of alien and native seeds; consequently, we ruled out the possibility that reduction in herbivore biomass was due to alien plants having smaller seeds.

\section{Biodiversity and Food-Web Structure}

As expected, the invasion reduced an originally diverse native forest to a depauperate vegetation dominated by one or a few alien species. The good fit of a quadratic function to the species-richness data presumably emerged from the delay between the arrival of alien plants and their first negative consequences. There was an initial increase in species richness followed by a sharp decrease (Table 1); thus, more species were present at intermediate levels of invasion. As stressed by Parker et al. (1999), "all invasions by one or more species at least initially increase the number of species in the community."

Compared with the native forest evenness was reduced in invaded areas, where the rich community of the native laurel forest had been replaced to a great extent by 4 highly competitive species: $H$. gardneranum, $C$. arborea, $P$. undulatum, and Leycesteria formosa. The decrease in evenness of the floral community is important because this evenness affects other trophic levels, particularly by increasing variability in seed production.

Biological invasions have the potential to disrupt the complex web of interactions among organisms. Nevertheless, when controlling for size of a food web (number of species in the web), the number of links, link density, connectance, and interaction evenness were not significantly affected by proportion of alien seeds (Table 2). Connectance is a central and by far the most widely used food-web index and can yield insights into the degree of specialization of a group of interacting species. Thus, generalist species tend to inflate connectance, and specialist species have the opposite effect. In our data, connectance was higher in invaded sites because specialist herbivores on native plants were replaced by more generalist species that could incorporate alien plants in their diet. This higher level of connectance, however, was more strongly associated with size of the food web than with level of invasion. This result suggests that alien plants reduce species richness and thereby size of the food web, which in turn affects food-web descriptors. To unambiguously determine the impact of alien plants on food-web structure, a less degraded system may be needed because at our sites their effect was confounded by their impact on size of the food web. Nevertheless, system degradation is almost certainly a widespread effect of alien plants, so our results are probably typical.

The positive relationship we found between species richness and elevation is contrary to one of the most well-established generalizations in ecology (i.e., species richness tends to decrease with elevation) (MacArthur 1972). In the Azores alien plants inverted this pattern by reducing species richness at low elevations, where the level of invasion was stronger. This is a counter-intuitive pattern that was driven by many species being restricted to the native forest, which now exists only at higher elevations.

\section{Insect Abundance and Biomass}

The importance of insects in maintaining ecosystem function is unquestionable. Here, we found that insect abundance was unaffected by the replacement of native vegetation by more competitive alien species. This result was mainly driven by the increase of some very small generalist species, particularly herbivorous Diptera from the genus Trisopsis sp. (Cecidomidae) (Supporting Information) feeding on alien plants, which replaced the larger native specialists feeding on native seeds. For example, Ilex perado fruits were preyed on by the endemic moth Argyresthia atlanticella, whereas seeds of the invasive $C$. arborea and $H$. gardneranum were preyed on almost exclusively by Trisopsis sp. Although insect abundance remained unaffected by invasion, insect diversity was significantly reduced, which constrained the range of species available for foraging predators. Moreover, insects emerging predominantly in late autumn are unlikely to be useful for insectivorous predators that have lost their usual food sources during the breeding season. Given that all insects are not equally useful as prey, insect biomass is likely to provide a more meaningful picture of the impact of alien plants on higher trophic levels (Saint-Germain et al. 2007). Here, we found a strong negative relationship between insect biomass and alien plant invasion.

The depletion of insect biomass in invaded areas is likely to have consequences that will cascade through the food web to the community and ecosystem levels because of the loss of high-quality food sources for insectivores such as spiders, birds, mammals, and amphibians. Birds and probably the endemic bat (Nyctalus azoreum) (IUCN 2000) can be especially vulnerable given that 
insect biomass is crucial to them at least during the breeding season.

\section{Variability in Seed Production}

The pattern of seed production throughout the year was different in alien- and native-dominated plots. Native plots, by virtue of their higher floral diversity, produced seeds throughout the seeding season (July to November). Highly invaded plots were dominated by a few species; therefore, seed production was highly variable in time. This was particularly obvious in the highly invaded plots in which seed production was very low in July and September and high in November. This could lead to gaps in the food supply and ultimately to the local extinction of consumers.

Interactions between alien plants and native species can be complex. For example, the invasive plant $C$. $a r$ borea is an important resource for the Azores Bullfinch in winter when other native foods are less abundant (Ramos 1996), but at high densities $C$. arborea outcompetes the native species that are important resources for this bird during the rest of the year (e.g., I. perado, Prunus lusitanica, Vaccinium cylindraceum).

\section{Predicting Insect Biomass Production}

Our predictions for overall insect productivity (insect biomass) inside the SPA under the 2 scenarios of total recovery and total invasion in the laurel forest were 392 and $128 \mathrm{~kg}$, respectively. Although these results are estimates determined from extrapolations, the difference between the 2 scenarios is sufficiently large to be informative for ecosystem managers. Thus, the worst-case scenario suggests that, in addition to the decrease in insect biodiversity, $67 \%$ of the insect biomass in seed-predation webs will be lost if the remaining native forest is replaced by alien vegetation.

\section{Conclusions}

Alien plant invasion simplified the structure of the laurel forest, replacing it with an impoverished and homogenized flora. In particular, the homogenization of plant structure and the loss of insect biomass are likely to have far-reaching negative consequences for ecosystem stability.

Food webs have been traditionally used in pure rather than applied research, although more recently they have started to be used to frame important questions in conservation. Ecological networks have already proved useful when framing hypotheses about the impact of biological invasions (e.g., Aizen et al. 2008; Bartomeus et al. 2008). Other areas where food webs have been successfully used include the safety of biological control agents (e.g., Carvalheiro et al. 2008), the impact of habitat degra- dation (e.g. Tylianakis et al. 2007), and the effectiveness of habitat restoration (e.g., Forup et al. 2008). The use of food webs as a tool in applied ecology would work to the advantage of both pure and applied ecologists. For example, if field sites host alien plants, there will be little or no resistance from other parties to test the impact of their removal on network structure and robustness, thus, allowing theoreticians to test their models against field data. Moreover, this approach would provide conservation biologists with predictions of the community-level effect of removing alien species, a hitherto unattainable goal.

\section{Acknowledgments}

We thank J. Deeming, B. Merz, O. Karsholt, K. Hortsman, K. van Achterberg, and P. Borges for their identification of insects; the LIFE-Priolo team, especially M. Santos and $H$. Laborda, for the valuable assistance in the field; $S$. Pearce, M. Pocock, P. Craze, K. Henson, and 3 anonymous reviewers for commenting on the manuscript and Fundação para a Ciência e a Tecnologia (Portugal) for funding R.H.H.

\section{Supporting Information}

Plot location (Appendix S1) and the lists of species and interactions per plot (Appendix S2) are available as part of the on-line article. The author is responsible for the content and functionality of these materials. Queries (other than absence of the material) should be directed to the corresponding author.

\section{Literature Cited}

Aizen, M., C. M. Morales, and J. M. Morales. 2008. Invasive mutualists erode native pollination webs. Public Library of Science Biology 6:396-403.

Bartomeus, I., M. Vilà, and L. Santamaría. 2008. Contrasting effects of invasive plants in plant-pollinator networks. Oecologia 155:761770.

Bersier, L. F., and G. Sugihara. 1997. Scaling regions for food web properties. Proceedings of the National Academy of Sciences of the United States of America 94:1247-1251.

Bersier, L. F., C. Banasek-Richter, and M. F. Cattin. 2002. Quantitative descriptors of food-web matrices. Ecology 83:2394-2407.

Brooks, M. L., C. M. D'Antonio, D. M. Richardson, J. B. Grace, J. E. Keeley, J. M. DiTomaso, R. J. Hobbs, M. Pellant, and D. Pyke. 2004. Effects of invasive alien plants on fire regimes. BioScience 54:677688.

Carpenter, D., and N. Cappuccino. 2005. Herbivory, time since introduction and the invasiveness of exotic plants. Journal of Ecology 93:315-321.

Carvalheiro, L. G., Y. M. Buckley, R. Ventim, S. V. Fowler, and J. Memmott. 2008. Apparent competition can compromise the safety of highly specific biocontrol agents. Ecology Letters 11:690700 . 
Davis, M. A., J. P. Grime, and K. Thompson. 2000. Fluctuating resources in plant communities: a general theory of invasibility. Journal of Ecology 88:528-534.

Dunne, J. A., R. J. Williams, and N. D. Martinez. 2004. Network structure and robustness of marine food webs. Marine Ecology Progress Series 273:291-302.

Ehrenfeld, J. G. 2003. Effects of exotic plant invasions on soil nutrient cycling processes. Ecosystems 6:503-523.

Fonseca, C., P. Prado, M. Almeida-Neto, U. Kubota, and T. Lewinsohn. 2005. Flower-heads, herbivores, and their parasitoids: food web structure along a fertility gradient. Ecological Entomology 30:3646.

Forup, M. L., K. E. Henson, P. G. Craze, and J. Memmott. 2008. The restoration of ecological interactions: plant-pollinator networks on ancient and restored heathlands. Journal of Applied Ecology 45:742752.

Freeman, M. F., and J. W. Tukey. 1950. Transformations related to the angular and the square root. Annals of Mathematical Statistics 21:607-611.

Gillespie, R. G., and G. K. Roderick. 2002. Arthropods on islands: colonization, speciation, and conservation. Annual Review of Entomology 47:595-632.

IUCN (International Union for Conservation of Nature). 2000. Nyctalus azoreum. In 2007 Red List of threatened species. Chiroptera Specialist Group, IUCN, Gland, Switzerland. Available from www.iucnredlist.org (accessed February 2008).

IUCN (International Union for Conservation of Nature). 2005. Pyrrbula murina. In 2007 Red List of threatened species. IUCN, Gland, Switzerland. Available from www.iucnredlist.org (accessed January 2008).

Keane, M., and M. Crawley. 2002. Exotic plant invasions and the enemy release hypothesis. Trends in Ecology \& Evolution 17:164-170.

Leeuwen, J. N. V., H. Schäfer, W. O. v. d. Knaap, T. Rittenour, S. Björck, and B. Ammann. 2005. Native or introduced? Fossil pollen and spores may say. An example from the Azores Islands. Neobiota 6:27-34.

Lonsdale, W. M. 1999. Global patterns of plant invasions and the concept of invasibility. Ecology 80:1522-1536.

Lopezaraiza-Mikel, M. E., R. B. Hayes, M. R. Whalley, and J. Memmott. 2007. The impact of an alien plant on a native plant pollinator network: an experimental approach. Ecology Letters 10:539-550.

Losey, J. E., and M. Vaughan. 2006. The economic value of ecological services provided by insects. BioScience 56:311-323.

MacArthur, R. 1972. Geografical ecology: patterns in the distribution of species. Harper \& Row, New York.

Mack, R. N., D. Simberloff, W. M. Lonsdale, H. Evans, M. Clout, and F. A. Bazzaz. 2000. Biotic invasions: causes, epidemiology, global consequences, and control. Ecological Applications 10:689-710.

Magurran, A. E. 2004. Measuring biological diversity. Blackwell Publishing, Oxford, United Kingdom.

Oliver, D. L. 1998. The importance of insects and lerp in the diet of juvenile regent honeyeaters, Xantbomyza phrygia: implications for the conservation of an endangered woodland bird. Wildlife Research 25:409-417.

Parker, I. M., et al. 1999. Impact: toward a framework for understanding the ecological effects of invaders. Biological Invasions 1:3-19.

Perneger, T. V. 1998. What's wrong with Bonferroni adjustments. British Medical Journal 316:1236-1238.

Ramos, J. A. 1995. The diet of the Azores bullfinch Pyrrbula murina and the floristic variation within its range. Biological Conservation 71:237-249.

Ramos, J. A. 1996. Introduction of exotic tree species as a threat to the Azores bullfinch population. Journal of Applied Ecology 33:710722 .

Renner, S. S. 2007. Structure in mutualistic networks. Nature 448:877879.

Rousseau, R., and P. Van Hecke. 1999. Measuring biodiversity. Acta Biotheoretica 47:1-5.

Saint-Germain, M., C. M. Buddle, M. Larrivee, A. Mercado, T. Motchula, E. Reichert, T. E. Sackett, Z. Sylvain, and A. Webb. 2007. Should biomass be considered more frequently as a currency in terrestrial arthropod community analyses? Journal of Applied Ecology 44:330339.

Sample, B. E., R. J. Cooper, R. D. Greer, and R. C. Whitmore. 1993. Estimation of insect biomass by length and width. American Midland Naturalist 129:234-240.

Sax, D. F., B. P. Kinlan, and K. F. Smith. 2005. A conceptual framework for comparing species assemblages in native and exotic habitats. Oikos 108:457-464.

Schäffer, H. 2002. Flora of the Azores a field guide. Margraf Verlag, Weikersheim, Germany.

Silva, L., and C. W. Smith. 2006. A quantitative approach to the study of non-indigenous plants: an example from the Azores Archipelago. Biodiversity and Conservation 15:1661-1679.

Sugihara, G., K. Schoenly, and A. Trombla. 1989. Scale invariance in food web properties. Science 245:48-52.

Tallamy, D. 2004. Do alien plants reduce insect biomass? Conservation Biology 18:1689-1692.

Tylianakis, J. M., T. Tscharntke, and O. T. Lewis. 2007. Habitat modification alters the structure of tropical host-parasitoid food webs. Nature 445:202-205.

Vitousek, P. M., C. M. Dantonio, L. L. Loope, M. Rejmanek, and R. Westbrooks. 1997. Introduced species: a significant component of human-caused global change. New Zealand Journal of Ecology 21:116.

Whittaker, R. J., and J. M. Fernandez-Palacios. 2007. Island biogeography: ecology, evolution, and conservation. Oxford University Press, Oxford, United Kingdom.

Wolfram Research. 1999. Mathematica. Version 4.0. Wolfram Research, Champaign, Illinois.

Zar, J. H. 1999. Biostatistical analysis. Pearson Prentice Hall, Englewood Cliffs, New Jersey.

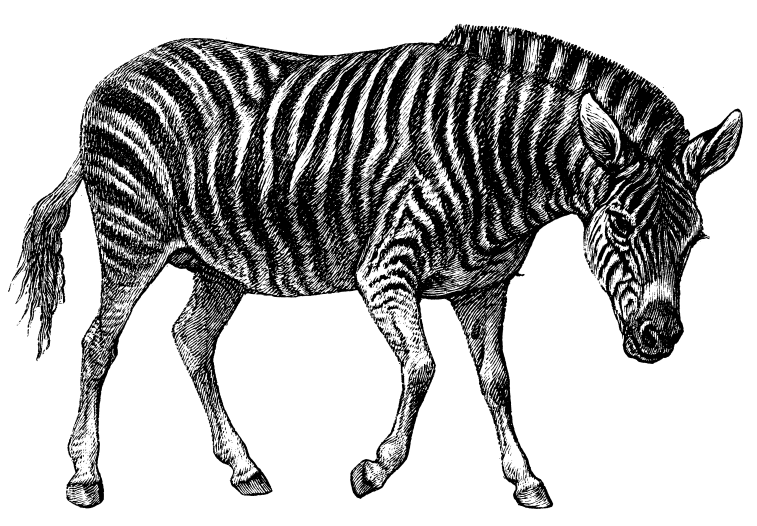

